\title{
INFLUENCE OF THE INDUCTION OF BREEDING ACTIVITY IN ANOESTROUS SHEEP ON THE LEVELS OF SOME CHEMICAL CONSTITUENTS OF UTERINE WASHINGS
}

\author{
R. B. HEAP,* D. M. ALLEN† AND G. E. LAMMING \\ University of Nottingham, School of Agriculture, Sutton Bonington, \\ Loughborough, Leicestershire
}

(Received 17th September 1962)

Summary. In two groups of anoestrous sheep ovarian activity was induced by injections of progesterone and pregnant mares' serum. All ten animals of the first group of maiden anoestrous sheep ovulated in response to the treatment but only three animals (30\%) showed behavioural oestrus. In the second group of eleven lactating sheep each animal ovulated but only two (18\%) showed behavioural oestrus.

The levels of several chemical constituents in the uterine washings (sodium, potassium, phosphorus, nitrogen, carbohydrate) were compared between maiden and lactating anoestrous sheep during the induced oestrous cycle. It was found that only the level of phosphorus was significantly different between the two groups and was greater in lactating sheep than maiden sheep at the induced oestrus and 10 days after oestrus. In both groups of sheep the results obtained during the induced oestrous cycle were significantly different from those of the normal breeding season which were previously reported by Heap (1962). The uterine washing of lactating sheep 6 weeks after parturition was contaminated with debris and blood and was not analysed. The results are discussed in relation to differences in fertility between lactating and maiden anoestrous ewes at the first induced oestrous cycle.

\section{INTRODUCTION}

Investigations have been reported on the use of progesterone-pregnant mares' serum (PMs) to induce breeding activity of anoestrous sheep (Dutt, 1952, 1953; Robinson, 1952, 1954; Gordon, 1958; Allen \& Lamming, 1960). Conception rate was higher in treated maiden sheep than in treated lactating sheep possibly due to a failure of fertilization (Allen \& Lamming, 1960) or implantation (Gordon, 1958).

The experiment described here was concerned with the chemical composition of uterine washings recovered at different stages of induced oestrous

*Present address: School of Agriculture, University of Cambridge. †Present address: Department of Agriculture, The University, Reading.

209 
cycles from anoestrous maiden and lactating sheep. The results are compared with those obtained during the normal oestrous cycle (Heap, 1962).

\section{METHODS AND MATERIALS}

\section{Animals}

A total of thirty-three sheep of mixed breeding were used, composed of ten maiden and eleven lactating sheep which received hormone treatment and twelve untreated lactating sheep. Two vasectomized rams were available during the experiment.

\section{Treatments}

The animals were treated with progesterone-PMs by the method previously described by Allen \& Lamming (1960). The maiden sheep were treated during March 1959 and the lactating sheep during May 1959 when the suckling lambs were 6 weeks old. The response to exogenous hormone therapy was assessed by visual examination of the ovaries during the recovery of the uterine washings.

\section{Recovery of uterine washings}

Samples were obtained by laparotomy at four or five stages of the oestrous cycle; 2 days before expected oestrus, at oestrus, and 2, 5 and 10 days after oestrus. Where samples were taken from animals 2 days before oestrus and at oestrus in the case of maiden sheep, and 2 days before oestrus in the case of lactating sheep, further uterine washings were also taken 10 days after oestrus. The technique for the recovery of uterine washings from the sheep has been described by Heap (1962).

\section{Analysis of uterine washings and presentation of results}

The method of chemical analysis and presentation of the results has been previously described (see Heap, 1962). The washings were analysed for sodium, potassium, phosphorus, nitrogen, and carbohydrate.

\section{RESULTS}

In maiden sheep treated with progesterone-PMs during the non-breeding season, all animals ovulated in response to treatment but only three $(30 \%)$ showed behavioural oestrus. The levels of several chemical constituents of the uterine washings were not significantly different at the four stages of the induced oestrous cycle (potassium, phosphorus, acid-soluble nitrogen, lipid nitrogen), but the values of total nitrogen and protein nitrogen were greater at oestrus than 2 days after oestrus (approached significance $P<0.05$ (Table 1)). At oestrus and 2 days after oestrus the levels of carbohydrate were considerably less than 2 days before oestrus $(P<0.05)$ and 10 days after oestrus (not significant).

In lactating sheep treated with progesterone-PMs, each animal ovulated in response to treatment but only two $(18 \%)$ showed behavioural oestrus. There 


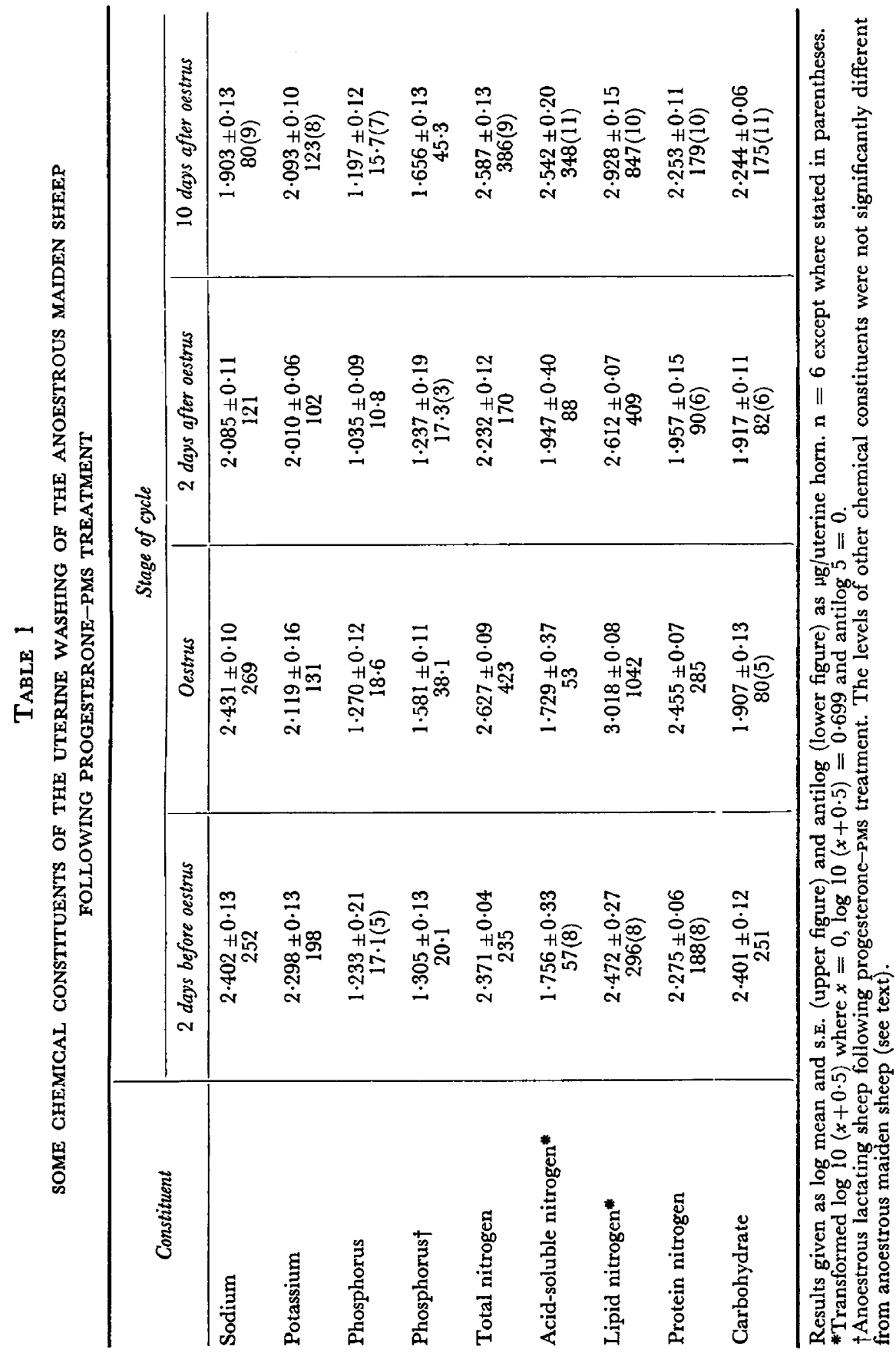




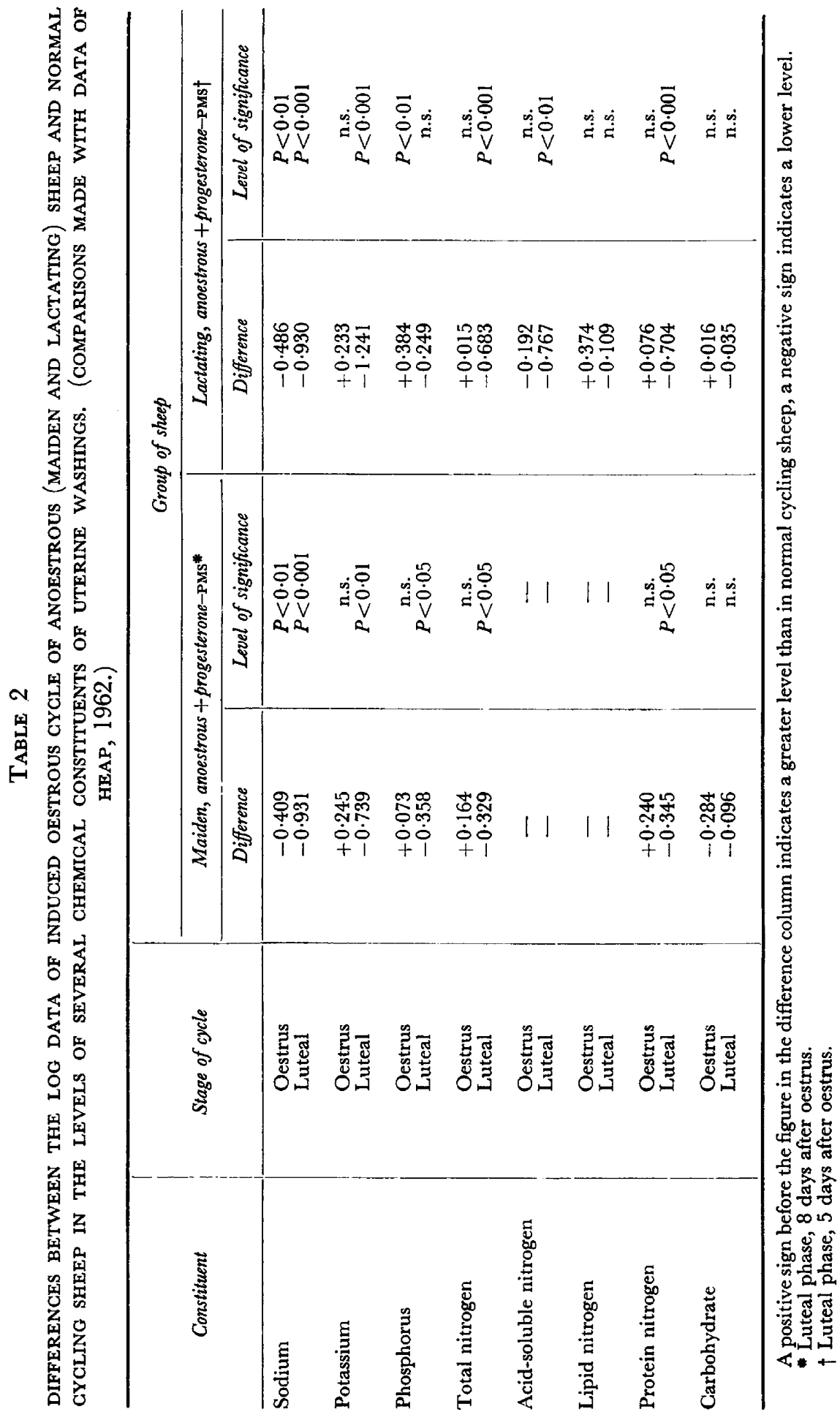


were no significant changes in the levels of the chemical constituents of the uterine washings at different stages of the oestrous cycle. In all untreated lactating sheep the uterine washings were grossly contaminated with blood and cellular debris from the uterine lumen and were not analysed.

The levels of several chemical constituents in the uterine washings of anoestrous sheep treated with progesterone-PMs have been compared with results obtained during the 'normal' oestrous cycle (Table 2). During the 'normal' oestrous cycle there were significant increases in the amounts of several chemical constituents of the uterine washing (sodium, potassium, total nitrogen, carbohydrate) during the luteal phase (Heap, 1962), but this was not confirmed in the induced oestrous cycle of maiden or lactating sheep.

TABLE 3

DIFFERENCES BETWEEN THE INDUCED OESTROUS GYCLE OF MAIDEN AND LAGTATING ANOESTROUS SHEEP IN THE LEVELS OF SEVERAL CHEMICAL CONSTITUENTS OF UTERINE WASHINGS

\begin{tabular}{l|c|c|c}
\hline \multicolumn{1}{c|}{ Constituent } & Stage of cycle & $\begin{array}{c}\text { Difference between } \\
\text { maiden and lactating } \\
\text { anoestrous sheep }\end{array}$ & $\begin{array}{c}\text { Level of } \\
\text { significance }\end{array}$ \\
\hline Sodium & Oestrus & +0.077 & n.s. \\
Luteal & -0.063 & n.s. \\
Potassium & Oestrus & +0.012 & n.s. \\
Luteal & +0.233 & n.s. \\
Phosphorus & Oestrus & -0.311 & $P<0.05$ \\
Lotal nitrogen & Oestrus & -0.459 & $P<0.05$ \\
Luteal & +0.149 & n.s. \\
Protein nitrogen & Oestrus & -0.173 & n.s. \\
Larbohydrate & Oestrus & -0.164 & n.s. \\
& Luteal & -0.117 & n.s. \\
& n.s. & n.s. \\
\hline
\end{tabular}

A positive sign in the difference column indicates a greater level in the maiden sheep than in lactating sheep and a negative sign indicates a lower level.

Luteal phase refers to 10 days after oestrus.

When the results of the 'normal' oestrous cycle and the induced oestrous cycle were compared, there were significant differences at the induced oestrus (maiden sheep had less sodium; lactating sheep, less sodium and more phosphorus) and the following luteal phase (maiden sheep had less sodium, potassium, phosphorus, total nitrogen and protein nitrogen; lactating sheep, less sodium, total nitrogen, acid-soluble nitrogen, protein nitrogen but more potassium).

Comparing the results in maiden sheep with lactating sheep, the only significant difference was the level of phosphorus which was greater in the latter both at induced oestrus and 10 days after oestrus (Table 3 ).

The ratios of several chemical constituents of the uterine washings have been calculated from the arithmetic data for maiden and lactating anoestrous 
sheep treated with progesterone-PMs and were compared with results obtained during the 'normal' oestrous cycle of sheep and reported previously by Heap (1962, Table 8). These results emphasize the difference in the levels of the chemical constituents of the uterine washings during induced and 'normal' oestrous cycles. Some ratios showed similar trends (sodium : potassium, total nitrogen : protein nitrogen, and sodium + potassium : total nitrogen) but in other cases there was considerable disparity (total nitrogen : acid-soluble nitrogen and carbohydrate : acid-soluble nitrogen).

\section{DISCUSSION}

Induced breeding activity of the anoestrous sheep (maiden and lactating) by the progesterone-PMs treatment of Allen \& Lamming (1960) produced ovulation in each animal but coincident oestrus was low $(30 \%$ in maiden and $11 \%$ in lactating sheep). The number of animals showing oestrus was considerably less than in other reports (Gordon, 1958; Allen \& Lamming, 1960), but the reasons for the failure of behavioural oestrus in these small groups of sheep are not understood. It has been shown in similar groups of sheep that the fertilization rate of maiden sheep which mated at induced oestrus was usually high (up to $88 \%$ ) but in lactating sheep it was low (0\%) (Allen \& Lamming, $1959,1960)$. The comparable figures in Gordon's experiments were $69 \%$ and $14 \%$, respectively. It would seem, therefore, that there is some additional factor which interferes with conception and implantation in the lactating sheep.

Gordon (1958) suggested that there was a failure of implantation in the lactating sheep and showed that fertility was markedly improved if the animals were mated at the oestrus following an induced ovarian cycle which thus simulated the 'silent heat' at the beginning of the normal breeding season. Allen \& Lamming (1960) reported the presence of spermatozoa within the zona pellucida of ova recovered after the first induced oestrus but an absence of fertilization. It has been found in the present experiments that the uterine washing of the untreated lactating sheep 6 weeks after parturition was contaminated with blood and debris. Following the induction of an oestrous cycle in the lactating ewe, the uterine washing was not contaminated with blood. This intrauterine debris may account for the low rate of fertilization in lactating sheep when induced to breed and the effect of a second induced oestrus may be to improve the uterine environment.

In the two groups of anoestrous sheep used in the present study, the levels of several chemical constituents of uterine washings recovered at induced oestrus and the following luteal phase differed significantly from the corresponding data of the normal oestrous cycle. There was also no cyclical variation in the levels of these chemical constituents which was a feature of the normal oestrous cycle of the breeding season noted by Heap (1962). When the results were compared between the two groups of anoestrous sheep (i.e. maiden and lactating) only phosphorus was significantly different (greater at induced oestrus and 10 days after oestrus in lactating compared with maiden sheep, $P<0.05)$. 
The results of this experiment suggest that the levels of several chemical constituents of uterine washings in seasonal and lactating anoestrous sheep induced to breed by progesterone-PMs treatment were different from those of the normal breeding cycle. These differences did not usually prevent fertility in other experiments with maiden sheep induced to breed with the same progesterone-PMs treatment. In lactating sheep induced to breed with the same hormone treatment (Lamming, 1961) fertility was much lower. The level of phosphorus in the uterine washings was significantly different from maiden sheep and the ratios of several chemical constituents were considerably different from the normal. This lowered fertility at induced oestrus may be associated with an unfavourable uterine environment which affects fertilization and embryonic mortality.

\section{REFERENCES}

Allen, D. M. \& Lamming, G. E. (1959) Factors affecting fertility in female sheep. University of Nottingham, School of Agriculture Report.

Allen, D. M. \& Lamming, G. E. (1960) The induction of breeding activity in lactating ewes during anoestrus. J. Reprod. Fertil. 1, 213.

DurT, R. H. (1952) Induction of estrus and ovulation in anestrual ewes by the use of progesterone and PMs. F. Anim. Sci. 11, 972.

Dutr, R. H. (1953) Induction of estrus and ovulation in anestrual ewes by the use of progesterone and pus. F. Anim. Sci. 12, 515.

Gordon, I. (1958) The use of progesterone and serum gonadotrophin (PMS) in the control of fertility in sheep. II. Studies in the extra-seasonal production of lambs. 7. agric. Sci. 50, 152.

HEAP, R. B. (1962) Some chemical constituents of uterine washings: a method of analysis with results from various species. F. Endocrin. 24, 367.

LAMming, G. E. (1961) The use of hormones to induce extra-seasonal breeding in sheep. University of Nottingham, School of Agriculture Report.

Robinson, T. J. (1952) Role of progesterone in the mating behaviour of the ewe. Nature, Lond. 170, 373.

Robinson, T. J. (1954) The production of co-incident oestrus and ovulation in the anoestrous ewe with progesterone and PMs. F. Endocrin. 10, 117. 